\title{
Silvana Malle:
}

\section{Institutional diversity and economic performance}

Definition and role of institutions. Institutions are diverse: examples from OECD countries. Does institutional diversity matter for comparative economic performance? The problem of measurement. Do institutions tend to converge or diversify further? What are the driving forces? What did we learn from institution building in transition economies? Need for a better understanding of interactions between institutions and policies. The OECD work and experience. Conclusion: the need for a vision.

\footnotetext{
* Silvana Malle is the Head of Division of Non-member Economies of the Economics Department, OECD and professor at the University of Verona. The views expressed in this paper are those of the author and do not necessarily reflect those of the OECD or the governments of its member countries. The author is grateful to her colleagues Rudiger Ahrend, J. Oliveira Martins, Charles Pigott and William Tompson, and to Prof. Julian M. Cooper for their valuable comments.
}

The paper was presented at the conference on "Institutional and Policy Diversity - Its role in Economic Development”, Debrecen, Hungary, 3-5, November, 2003. 


\section{Introduction}

The issue of market-oriented institution-building has been at the core of the economic transformation process and debate. Institutions have been by and large modeled on those of advanced market economies under the influence of assisting international organizations or under EU economic and political integration's requirements, but also under the pressure of developing market forces. In some countries this process has been relatively smooth; in others it has been painful and has yet to be completed.

Overall, experience shows that, while there remains a great deal of institutional diversity among both transformation economies and advance market economies, the pressures for convergence to best practices are strong. In any country vested interests try to resist institutional change, but in open economies market incentives are powerful vehicles of institutional adaptation to the demand for competitive markets, transparency, contract enforcement, and independent regulators when regulation is needed. Nonetheless, this is not a mechanical process. Cross-countries studies on institutional diversity help to single out the relevant interactions between policies and institutions. Path-breaking research is now trying to measure the impact of diverse institutions on economic performance.

There are lessons that can be learnt from transition economies on the speed of, and constraints to, institutional change. This paper focuses on the lessons that are seen as the most relevant to the topic of this conference. The most controversial question is whether there is room in a globalised economy for a spontaneous evolution of institutions or institutional change needs external pressure.

OECD experience shows that sound policies and institutions as well as their synergies matter for stability and growth. But, while economic analysis by and large has identified the type of linkages between macroeconomic policies and institutional reforms necessary to preserve stability and sustain growth, the time needed for implementation of policies and functioning of new institutions is a path dependent variable that makes outcomes unpredictable.

Thus, this paper argues, there is need for a vision and sense of direction. Clear political commitments can help bridge the gap between decision-making and actual enforcement, thus reducing risks for economic agents.

\section{Definition and role of institutions}

Institutional economics is nowadays a well articulated and developed body of economic science. Structural reforms -- that mainly concern institutional adjustment - have become an integral part of the IMF conditionality attached to its various programmes of lending. An increasing part of the OECD work is now devoted to the analysis of how economic institutions work and ways of improving their effectiveness. In the economic literature the debate between neoclassical economics and institutional economics is not anymore one of " either-or" but rather one of emphasis and degree.

For the purpose of economics, "institutions are the rules of the game in a society, or, more formally, are the humanly devised constraints that shape human interaction". [1] Others 
include in economic institutions also organisational entities, procedures and regulatory frameworks: in this perspective commitment devices such as the independence of the Central Bank, a balanced budget rule, and international trade agreements should also be included among economic institutions. ${ }^{[2]}$ The function of institutions is to create order and reduce uncertainty in exchanges, thus, they determine transaction and transformation costs and hence the profitability and feasibility of engaging in economic activity. ${ }^{[3]}$

While institutional economics is about the importance of institutions in framing economic relations, expectations and results, there are broader philosophical differences among institutional economists that underscore different assessments as to the role institutions should play in bettering economic performance. There is debate on issues such as the primacy of society over the individual or vice-versa, behavioural versus rationalistic decisions, institutional adaptation to change versus invisible-hand processes, and the role of governmental intervention in the allocation of resources and in the system of institutions. Different positions on these issues, in turn, have a bearing on how broad, strong or flexible a regulatory framework should be and what should be the role of the state versus that of individual agents in a market economy. While this difference in perceptions can be better seen in comparing the Old Institutional Economics (OIE) with the New Institutional Economics (NIE), undercurrents in each school of thought happen to share common views or to distinguish themselves sharply from their own school mainstream. ${ }^{[4]}$ From a practical and prescriptive point of view, one needs to stress that a different emphasis on the role of government in institution building would necessarily permeate their type, quality and responsiveness to change.

There is also an important methodological difference among institutional economists with some concentrating on the historical evolution of institutions and others adopting a more normative-static view. For the most eminent representative of the historical approach, Douglass C. North, institutions connect the past with the present and the future so that history is a largely incremental story of institutional evolution, and a path-dependent pattern of history explains historical (comparative) economic performance. ${ }^{[5]}$ Within this approach it would be difficult to maintain that institutions can be transplanted to, and in a short time be made to be functional in other regions/cultures. Transplanting of institutions is, however, what has occurred and is still taking place in a number of transition countries and, to a certain extent, in other emerging market economies (EMEs). This has occurred primarily under a normative approach to institution building used by the assisting international financial and economic institutions.

\section{Institutional diversity}

While the historical approach necessarily makes room for institutional diversity, the normative approach tends to dismiss the sources of institutional diversity and to advocate the establishment of common institutions. While the former approach provides little scope for (rapid) institutional change, the latter forces, to a more or less important degree, the pace and quality of market-friendly institutional change. While the path-dependence approach to institutions cannot offer immediate policy prescriptions to countries that try to catch up with more advanced economies, the normative approach is bold in believing in institutional adaptation through creative destruction and provides a vision, though no assurance that forced institutional change will work. ${ }^{[6]}$ 
Traditional comparative economics is perhaps better placed than other fields of applied economics to appreciate the impact of institutional diversity on development and growth. On the one hand, this branch of studies was instrumental for the analysis of profoundly different rules of the game in planned economies and their results and performance; on the other hand, it was also important in drawing the attention to informal rules that helped the real economies to function where "command" principles had failed. Some could argue that there remains little room for comparative economics after the collapse of communism and its economic system. Most of the experts in this branch of studies have turned to transitional economics somehow following, and adjusting their skills to, economic transformation in Eastern Europe and Central Asia. Some have themselves become major protagonists of this transformation having been appointed to highly relevant governmental positions or turned into successful private businessmen.

International institutions are increasingly finding the distinction between transition, developing and developed economies irrelevant in mapping scales or clusters of economic performance. One study, conducted on the basis of indicators of institutional quality, submits that transition economies as a group are no longer distinguishable from other economies. ${ }^{[7]}$ At the same time, however, this study maintains that transition economies are very diverse in terms of their institutional conditions. One should note that diversity is characteristic also of OECD countries: indicators of transparency and corruption, for instance, ranks them at disparate levels. ${ }^{[8]}$ Though most of these indicators are based on perceptions, rather than hard facts, they portray a spectrum of institutions and institutional performance that would be hardly compatible with a unified and abstract approach to market institutions and their effect on development and growth.

One might tentatively argue that, while there is little scope for systemic diversity -though a major outstanding exception is communist China - institutional diversity remains prevalent and in itself an interesting subject for research on institutional stability and change. Loci of diversity among advanced market economies are found in the nature of the legal system, the role of the public sector, regulatory frameworks, as well as in corporate governance, financial markets, labour markets and social insurance mechanisms. All these institutions are under a continuous process of evolution and change and they interact among themselves and with economic policies. The impartiality and adaptability to change of the judiciary are linked to the nature of the legal system. There is not a single mind on what should be the size and role of the public sector. Recent corporate scandals have brought to the attention the need for checks and balances in the structure of corporate governance, accounting and auditing in most advanced economies. The performance of financial markets is increasingly being linked to their regulatory framework. The comparative flexibility of the labour market is at the forefront of the debate on the lower growth potential of most European countries versus that of the United States. Ageing populations in advanced economies are forcing market-oriented reforms to the increasingly unsustainable Pay-as-You- Go pension systems.

\section{Does institutional diversity matter for comparative economic performance? The problem of measurement.}

In the recent debate on the constraints on growth that is linked to the broader theme of poverty reduction, endogenous versus exogenous constraints and ways to overcome a possibly widening gap between rich and poor countries have been discussed. According to Jeffrey 
Sachs institutions matter, but geography and resource endowment are more important obstacles. ${ }^{[9]}$ With no external aid, path dependence can bring unfavourably placed countries further down to total collapse and decimate their population. Thus, Sachs argues for direct intervention against illnesses, transportation traps, depletion of land. Sachs' remains, however, an isolated voice among policy-oriented economists and one exposed to the criticism based on hard facts. The successful development stories of Botswana, compared to the difficulties in Angola and Zimbawe in Africa, as well as Singapore, compared to lower income equatorial countries in Asia, put in question the primacy of geography in explaining economic regression and failure. Moreover, the squandering of many international aid programmes by corrupt governments raises legitimate questions as to whom aid should be delivered, who should be in charge of implementation and who should be made responsible for its effects. Thus the role of institutions, as recipient of aid, comes again to the fore.

For Dani Rodrik and Arvind Subramanian the quality of institutions matters much more than geography and international trade in explaining the gap between rich and poor countries. They measure the quality of institutions by a composite indicator of a number of elements that capture the protection afforded to property rights as well as the strength of the rule of law. Their conclusion is that institutional quality can boost income significantly, while global integration and geography on their own do not. The coordinates of a well performing institutional system are complex. Rodrik and Subramanian note that contract enforcement needs market creating institutions, that is institutions without which the market could not function or perform very poorly. But they also point to the need for market regulating, market stabilising and market legitimising institutions to make growth sustainable. ${ }^{[10]}$ This typology brings into the institutional picture also macroeconomic tools and procedures. While on the one hand regulatory agencies are needed to cope with externalities, economies of scale and imperfect information, on the other, the legitimation of the market needs social protection, redistribution and management of conflicts that imply, for instance, the establishment of pension systems and social safety nets. Since economies need also to build resilience against shocks and financial instability and ensure a stable macroeconomic framework, institutions governing central banks, exchange rate regimes and budgetary and fiscal rules also matter. The issue of a larger role for public deliberation and measures of democracy becomes preeminent in explaining long-term income levels. Reforms that aim at those institutional changes may have to involve political confrontation with some of society's powerful and entrenched interest groups. ${ }^{[11]}$ There is need for a vision of where society wants to go and, therefore, a political arena where different interests and the consequences of their actions are openly debated.

Following a formalist approach, that is increasingly fashionable in the NIE, others have tried to measure the effect of institutions on growth. An interesting project on the institutional features of different countries carried out in France suggests that countries can be grouped into four clusters: on the basis of their institutional characteristics defined as moderate liberalism, pure liberalism, authoritarian paternalism and informal. The institutional identity of countries is revealed by essentially four determinants: public governance, innovation, security of transactions and regulation. The resulting institutional diversity that the authors measure on the basis of multiple indicators is found to matter for economic development. ${ }^{[12]}$ The IMF's index of aggregate governance measure shows a clear crosscountry relationship between income per capita and institutional quality. ${ }^{[13]}$ The index measures the overall quality of governance, including the degree of corruption, political rights, public sector efficiency and regulatory burdens. The index relies on six underlying measures of institutional development developed by the World Bank. ${ }^{[14]}$ These measures 
are:1) voice and accountability, i.e., the extent to which citizens can choose their government, political rights, civil liberties and independent press; 2) political stability and absence of violence, i.e., the probability of government changes through unconstitutional or violent means; 3) government effectiveness, which measures the quality of public service delivery and competence of the civil service; 4) regulatory burden, which measures the relative absence of government controls on goods markets, the banking system and international trade; 5) rule of law, i.e. the protection of persons and property against violence and theft, independent and effective judges, contract enforcement; and 6) freedom from graft, meaning the absence of use of public power for private gain or corruption.

The correlation between institutional performance and growth results even stronger when measures of property rights (degree of protection of individual property rights based on a progressive scale from 1 to 5) and constraint on power of the executive are included reflecting institutional and other limits placed on the president and other parts of the executive (rated on a progressive scale from 1 to 7 ). ${ }^{[15]}$

The obvious problems with this type of approach are that: a) it does not say anything on the direction of causality; b) most measures are influenced by preferences and perceptions; c) the ordering of countries according to institutional quality is likely to be subject to shortterm changes depending on the time span of the observations; d) it is not clear how synergies and interactions among institutions and between institutions and policies are measured and finally e) the aggregation of several indices is always problematic. Perceptions are influenced by the new information made available at any point in time, while there is no reason to expect that quality of any institution by itself would abruptly change over a short time. Regulatory devices may seem to be functional but only experience will show whether they are. The BIS criteria of capital adequacy and bank supervision, for instance, have been shown to be rather inadequate to prevent banking crises in transition countries and EMEs. Few questioned the wisdom of corporate governance rules in the United States until the Enron case revealed fundamental flaws. Finally, a legitimate question is whether it is the smoothness of interactions among institutions that matters rather than the quality of each institution as such.

The constraint on the executive - that advanced economies and developed societies may well accept as useful criteria for the quality of the government -- does reflect a value judgment that, if embodied in economic policy prescriptions, could turn out to be detrimental to progress in less developed economies. ${ }^{[16]}$. There is no linear and universal relationship between the dispersion of power and economic growth. Different countries face different dictatorship-disorder curves: a comparison between Central European Countries and Russia along this approach could provide interesting insights. In some circumstances, the concentration of political power at the government level, rather than its diffusion, could be a decisive factor for economic growth. On this end of the spectrum, China obviously gives room for thought. ${ }^{[17]}$ On the other hand, one should also remember that dictatorship did not help several Latin American countries to establish and sustain performing market economies.

The main difficulty with any aggregate measurement of institutional quality so far is that they embody as values the historical institutional developments of western societies. While the results of econometric analysis may well portray a broadly functional institutional framework that less advanced economies may wish to adopt, whether transplantation is feasible at a certain moment in time and how to adapt these institutions to a different social organisation and a different level of economic development remain an open issue. 


\section{Do institutions tend to converge or diversify further? What are the driving forces?}

In advanced market economies the process of institutional change is driven by well established market forces and interest groups acting within a legal framework that guarantees the expression and resolution of conflicts. Inherited legal frameworks, such as English common law or French-Napoleonic civil law (largely based on Roman law) provide a common basis for change. Basically similar constitutional provisions and political systems also provide both the contours and the means to adapt institutions to new demands. These demands themselves stem from an increasingly integrated process of growth and development, where the economic actors have to play according to some common rules of the game and they all have interest in reducing their transaction costs.

Economies of scale create incentives to expand production and world markets. OECD economies command the largest share of international trade and foreign direct investments. Banking, security markets and firms, and insurance provide the necessary financial networks. The process of institutional convergence to best practices that helps reducing international transaction costs is facilitated by the existence of different kinds of international organisations. Some organisations like the European Union have broader political goals and perspectives and own institutions and ruling that through a complicated negotiation process are capable of forcing institutional change among their member and prospective accession countries.

Other organisations, like the OECD, provide a forum for policy dialogue that also results in institutional change through the dissemination of information on best practices, multilateral surveillance -- that increasingly encompasses institutional performance - and, finally, agreements or conventions that bind the signatories to adapt their national legislation to the object of the agreement. The process by which upgrading and adjustment of institutions is brought about is one of facilitating mutual knowledge, policy dialogue and persuasion. This process, formerly limited to OECD member countries, is now gradually being extended to non-members in the belief that globalisation would benefit from a more pro-active policy on the part of OECD member countries vis-à-vis their partner economies. A successful example of this process is the Convention on Combating Bribery of Foreign Public Officials in International Business Transactions, signed on 17 December 1997 by 34 states, including five non-member states, that compels each signatory to introduce legislation against public officials demanding or accepting bribery while involved in economic transactions.

However, it is clear that, even within a context that is particularly favourable to the development of common institutions, the process of institutional change is one of marginal changes to existing institutions that have been shaped by different historical patterns and culture. The legal tradition may have an influence on how fast institutions adapt to socioeconomic change. Measured cross-country differences in the development of financial intermediation, stock market and private property rights protection indicate, for instance, that French legal origin countries are more likely to develop inefficiently rigid legal systems than British Common Law and German Civil law countries with adverse repercussions for financial development. ${ }^{[18]}$ As argued by Beck et al., while institutional adaptability is facilitated by legal systems that embrace case law and judicial discretion, it is constrained by legal systems based on statutory law. The Common law is inherently dynamic as it responds 
case-by-case to the changing needs of society. Similarly the German law provides for more flexible adaptation having maintained its historical roots in jurisprudence and judicial discretion. To the contrary, it is argued, distrust of judges and jurisprudence in the French legal tradition - that finds its root in French history, arbitrary power of kings and corrupted justice appointed by them, had adverse implication on financial development. ${ }^{[19]}$

While the process of international integration militates for the development of common institutions and this process is being facilitated by international agreements, or even forced by IMF conditionality clauses attached to lending, institutional convergence is developing very slowly among advanced economies due to a large extent to their historical path dependence, in which legal tradition plays a very important role. But, all in all, the main economic players work for institutional convergence to best practices. This can be observed in most if not all the market regulating, stabilising and legitimising institutions.

However, as noticed above, doubts that transplanting institutions to other countries/cultures will work and further global institutional convergence to best practices are legitimate. The point that the transplanting of institutions is difficult and may exacerbate their original weaknesses in the absence of socioeconomic forces pushing for change is well made in the discussion by Beck et al. of the difficulties associated with the export of the Napoleonic doctrine to the colonies. ${ }^{[20]}$ More recent examples, and mixed results, of institutional transplanting, particularly among market regulating and legitimising institutions, can be found in transition economies.

\section{What did we learn from institution building in transition economies?}

There are several lessons from the unique experiment of institutional change in postcommunist transition countries, some of which have been digested, while some have still to be better understood. In the context of this paper five lessons appear to be relevant.

The first lesson is that demand for institutional change did not, and could not, come from countries abruptly undergoing systemic change after the disintegration of the political system they had been subject to for decades, no matter how able, qualified and prepared to change their new leaders were. In spite of broad social support for democracy and freedom, the web of incentives, motivations, and expectations linked to the very unique (communist) institutional framework not only could not deliver the demand for change, but was resistant to, or afraid of, change. The new order - market creating institutions, such as constitutional provisions on property rights and contract enforcement- had to come from without either through conditionality, or persuasion, or foreign investments. ${ }^{[21]}$ This process, that primarily consists in introducing new rules of the game, was not easy, has found resistance in vested interests or simply incomprehension, is not yet completed and, finally, its implications are not yet fully understood. While the rule of law is the major tenet of institutional economics, what is needed for introducing de facto and implementing the rule of law is far from clear. ${ }^{[22]}$ Even more problematic is whether the establishment of the rule of law is a pre-requisite of economic development, or is a product of development and growth.

The second lesson, and a corollary of the first, is that new institutions could not be transplanted as such from more advanced economies (East Germany was an exception) or under pressure from the IFIs but had somewhat to adapt to each country's capacity of institutional absorption and were subsequently subject to continuous changes. This occurred 
with market creating institutions as well as with other institutions aimed to regulate or legitimise the market. As an example, the bankruptcy law was changed three times in Russia, after being modelled on foreign law provisions. The first law did not work at all to its purpose. The second was twisted to the interest of the most powerful, either via tax administration or powerful businessmen and brought about an excessive number of perhaps avoidable bankruptcies. The third, approved recently, represents a further improvement, but also has own limitations. ${ }^{[23]}$ Bank supervision rules have been continuously changed overtime in most transition countries to cope with the developments of the banking system. Social safety nets, introduced in support of (or to legitimise) labour markets, came to be either too generous or ineffective, and have also undergone changes. In all these, and similar cases, however, institutional adaptation was facilitated by a fast learning-by-doing process among all agents that could have hardly been possible, had the initial institutional change not taken place

In many countries, continuous change was needed to stabilise market institutions, too. Rules governing monetary policy and Central Bank independence were introduced at different times and subsequently changed. Fixed exchange rate policies leading to fast real appreciation and loss of competitiveness ended up in devaluation and were replaced with managed floating regimes. Structural budget rules were introduced only after debt-payment crises. But a viable system of fiscal federal relations is nowhere in place in EMEs. Local governments and municipalities are limited in their autonomy to raise revenues in order to finance expenditures: in many countries this continues to feed abuse of power and corruption.

The third lesson is that countries that opened faster to foreign direct investments (FDI) were better able to upgrade their institutions since the demand for institutional quality came from the healthier business climate these investments helped to create. Faster integration in the regional (European Union) and world economy also sustained this momentum. Countries that were set to join the European Union had to rapidly adapt their legislation to the EU Acquis that in turn facilitated foreign investments. ${ }^{[24]}$ But, even apart from regional integration programmes, FDI helped recipient countries to quickly upgrade their banking and financial institutions and put pressure for the enforcement of contracts. ${ }^{[25]}$

The fourth lesson is that the new institutional order came better to function when countries' authorities were willing and able to take responsibility for institutional change and be strongly behind reforms. This is what the IMF, in particular, has learned after intervening heavily in the process of change with conditionality that became too pervasive and proved to be counterproductive. New IMF guidelines on conditionality issued in September 2002 emphasise "the need for parsimony in the application of conditionality, to focus on measures that are critical to a programme of macroeconomic objectives"..[26]

Finally, new market institutions settled better in countries that had a longer history and culture of market development before communism. In some countries individual property rights to land were never abolished; though circumscribed, forms of market economy had survived or expanded before transition and some efforts to move to market institutions under communism had helped to shape a set of mind for, if not the embryos of, further institutional change. What is perhaps more important, society as a whole accepted the new rules of the game. 


\section{Need for a better understanding of the interactions between institutions and policies. The OECD work and experience.}

Failures of transition reforms to deliver results in a short term and the occurrence of financial crises have put in question the design, timing and coherence of such changes and the advice on transition policies from international organisations. One of the most eminent critics is Joseph Stiglitz. ${ }^{[27]}$ His main contention is that (outside) reformers misunderstood the foundations of the market economy as well as the basics of the institutional reform process, since they underestimated the importance of informational problems, social and organisational capital and the institutional infrastructure required to make an effective market economy. Stiglitz criticises in particular rapid mass (voucher) privatisation and the early opening of capital account, the sequence and fast pace of reforms. He contrasts China with Russia. His alternative view is that decentralisation should have been seen as a solution to restructuring. By this Stiglitz means the (vertical or horizontal) disintegration of large firms into separate semi-autonomous teams or profit centers within a federal structure, or into separate businesses through spin-offs. Central managers would give up part of their power to younger middle managers, thus eliminating the cross subsidies that exist in large organisations. The pressure for the center to cede power should come from the constituent stakeholders (workers, creditors and other interested parties) that are interested in restructuring. Breaking monopolies would allow freedom of exchange (supply and demand outside the large organisation); decentralisation and outside competition would be the social learning mechanisms driving restructuring. This in turn will lead the process of rebuilding social capital.

While some of Stiglitz's arguments against the design and sequencing of reforms, and in particular his criticism of mass privatization, are worth considering -- though many transition economies chose alternative routes -- his own proposal sounds even more problematic. It is difficult to see how reforms could have come from below: why would workers have militated for the disintegration of large enterprises, that notoriously granted better remuneration and other benefits?; why would other stakeholders, whether banks or other enterprises, have put pressure for disintegration, that, at least in the short-term, would reduce the chance of recovering their claims? Indeed, one of the most common features in all transition and some other emerging market economies is the problem of recovering creditors' claims (collateral): this is mainly due to a cumbersome and socially bent judicial system, but also to an uneven protection of individual property rights.

On the other side of the spectrum, China's development path based on incremental changes suggests that economic growth can be spectacular, as noted by Stiglitz. But China's developments cannot be separated from the rule by a single (communist) party: an important institutional diversity that allowed China to set the direction, mode and pace of change in such a way that only an authoritarian system could do.

An increasing number of studies now contest the once broadly undisputed policy prescription that introducing democracy and the rule of law is essential in gearing a system towards market based economic development. Diversity at this very crucial institutional layer perhaps is what one needs to accept to pave the way to systemic change in countries with no democratic tradition. Djankov et al. argue that institutional diversity can in part be understood in terms of the fundamental tradeoff between controlling dictatorship and disorder. ${ }^{[28]}$ While, on the one side, investment must be secured by the government from theft, bribery, expropriation and so on, the government itself can become the violator and thief. A viable institutional design must provide for a balance between controlling disorder (private 
subversion of public institutions, such as courts, through bribes and threats) and dictatorship (risk to individual and their property of expropriation by the state and its agents, in several ways, including taxation and violation of property). At a level of less than fully fledged market development, there is room for institutional diversity. Djankov and al. describe interesting alternatives based on the higher effectiveness of private orderings and market discipline compared to public intervention, but also argue for public regulation. The government can create rules governing private conduct and then leave their enforcement to private litigation. There obviously remains the risk of abuse by public officials and/or state capture. At any rate there is a tradeoff between dictatorship and disorder that can provide the paradigms for institution building and institutional change in societies at different levels of development.

On more general terms, one can argue that periods of benevolent and enlighten despotism have often historically preceded the installation of democracy. But what if history does not leave such an option as in the case of collapse of communism in Eastern Europe and Russia?

All in all, transition to democracy and market has been less painful and more successful that many experts of planned economies would have expected on the score of the increasingly unsustainable path of extensive growth on which that model was based. There have been mistakes, failures, banking and financial crises but this could have hardly been avoided in a process of systemic change where the new leadership itself had to decide, appease social concerns, introduce new legislation to prevent institutional vacuum and anarchy with no previous knowledge of how to better manage the changes.

Still missing in Stiglitz's and many other ex-post appraisals of transition policies, and what is becoming a promising field of research, is an effort to understand the necessary linkages between macroeconomic policies and institutional reforms that help smooth the path to sustainable growth. Mutually supportive macro-structural policies and reforms in many cases have been, and frequently still continue to be, severely compromised by either wrong, or wrongly timed, policy decisions, lack of interdepartmental communication and coordination or delays in implementation. The IMF finds that, while policy variables do not appear as significant determinants of the level of income when institutional quality is taken into account, policies do contribute to explain growth and volatility. ${ }^{[29]}$

Work done in the OECD on several transition and EMEs shows that both policies and institutions, as well as their combined effects matter for stability and growth. Although no quantitative analysis has been made, empirical evidence confirms that fiscal and monetary policies impact each other, and have a bearing on real and financial markets. As one of the leaders of transition in Poland noticed, "fiscal policy is the greatest pressure upon monetary policy, at least in much less institutional(ised) and less mature economies". "20] At the same time development, or lack of development, in structural areas, i.e. a poor institutional framework (through excessive regulation and social protection, and weak property rights) has an impact on macroeconomic policies and performance. For instance, lack of development of financial markets and a low level of financial intermediation restricts the number of available monetary mechanisms to control inflation. Lack of collateral hampers lending to, and growth of, small and medium enterprises - while large scale enterprises may more easily have access to foreign lending - slow down the re-allocation of labour and the increase in employment and, and finally, raise the cost of the social safety net to the budget. If social spending cannot be reduced, increased revenues will have to be financed either through increased taxation or 
public debt. The temptation to increase public debt is strong, if the government is concerned about social consensus and if (domestic or foreign) lenders are eager to lend, which often occurs owing to higher interest spreads in EMEs. External vulnerability increases as the debt to GDP ratio may soon become unsustainable. ${ }^{[31]}$ Similarly, rigidities in the labour market can produce spiraling negative macro (reduced productivity potential and output growth) and structural effects (through negative effects on competition in the products market).

There is now a better understanding of the mechanism through which the liberalisation of capital movements can increase the probability of a financial crisis. Few would disagree, after the Asian, Russian and Latin American crises that adequate financial institutions are needed before fully liberalising the capital account. Capital control mechanisms may be useful to stem the inflow of speculative capital. On the other hand, free capital movements help to deepen the financial system. Controls on capital inflows and outflows retard this developments and may trap a country at a low level of economic and institutional development.

Underlying the unfavourable macro-structural linkages described above there are social and political developments: for instance the emergence of strong pressure groups organised around large scale enterprises and urban areas that would influence public choice in their favour. According to some scholars, this intricate economic, institutional and behavioural web of interactions stemming from weak property rights and distorted incentives may lead to stagnation. ${ }^{[32]}$

To have a better understanding of these linkages would also need serious work on the relations between any particular organisation of the state and economic agents. In some countries, line ministries are still powerful and their vested interestes compromise the design and implementation of new institutions. Reforms of the civil service are resisted by entrenched interest of public employees, whose support government needs. There also are bizarre deals, such as the one between the Russian President Putin and top businessmen granting them freedom of economic action provided they withdrew from politics, that in the end could turn to be quite unproductive if examined in the light of what structural changes are needed to attain the technical production frontier from an institutional economics' point of view.

Indeed, based on the interrelationship between the state, property rights and productivity that emerge from North's work on institutions, the set of feasible forms of economic organisation is defined by the system of property rights. The latter depends on the community's political structure. Securing property rights entails the owner's ability to consume, obtain income from, and alienate the assets over which he/she has rights. While the stock of knowledge and endowment of resources determine the technical production frontier, there is a structural production frontier that depends on the system of property rights. The notoriously weak contract enforcement system in Russia would suggest that the structural production frontier in Russia is rather far below the technical production frontier. New institutions take time to become performing: the institutional vacuum is filled by informal institutions. Thus there is need for a clear vision on the part of the leadership on where a country wants to go. Based on North's premises, one would argue that to move the structural frontier closer to the technical frontier needs political changes that would reduce the transactions costs associated with the existing structure of property rights. But the political compromise on which Russian political order seems to be based hints to a low probability of further political changes, that are exactly what is needed at the present stage of economic 
transformation. If, on the other hand, as it recently occurred, the unwritten contract is breached, this could be interpreted as a further fall of the structural production function down from the technical frontier due to higher transaction costs associated with political retaliation and weakening of property rights.

While it is difficult to quantify the effects of such type of behaviour on economic growth, since other variables are at play, it is possible to infer that Russia has not yet reached a stable institutional order and that the unclear rules of the game may deter domestic and foreign investment, create economic instability and hamper the prospects for sustainable growth. Evidence from Russian regions suggests that Russia is undergoing a process of institutional subversion sustained by preferential treatment to the largest regional firms that, thanks to political influence increase their market share in spite of lower labour productivity, and that this process adversely affects small business growth, tax collection and social public spending. ${ }^{[33]}$ Contrary to what many Russian scholars seem to believe, this is not unique to Russia, as the following quote indicates.

"The interventionist and pervasively arbitrary nature of the institutional environment forced every enterprise, urban or rural, to operate in a highly politicised manner using kinship networks, political influence, and family prestige to gain privileged access to subsidized credit, to aid various stratagems for recruiting labour, to collect debts or enforce contracts, to evade taxes or circumvent the courts, to defend or assert titles to lands. Success or failure in the economic arena always depended on the relationship of the producers with political authoritieslocal officials for arranging matters close at hand and the central government...for sympathetic interpretations of the law and intervention at the local level when conditions required it. Small enterprise, excluded from the system of corporate privilege and political favors, was forced to operate in a permanent state of semiclandestinity, always at the margin of the law, at the mercy of petty officials, never secure from arbitrary acts and never protected against the rights of those more powerful "[34]

This was 19th century Mexico, a country that has become member of the OECD only in the mid-90s. If Russia wants to advance fast towards meeting the requirements of an advanced economy, a deep rethinking of how better secure property rights from bureaucratic and political influence is needed. But it is unclear how the economic-political interplay that is necessary to attain a higher level of institutional performance can improve as long as conflicting but legitimate economic interests are barred from enter the political arena

\section{Conclusion: the need for a vision}

Past and present historical developments and recent systemic changes show that there is large institutional diversity among countries. This diversity is anchored on path dependency and social customs, but forces of international integration work to smooth institutional diversity and to bring economic institutions up to a level of generally acceptable functionality and performance. It is, to a certain extent, up to each country/government to stimulate the gradual reduction of institutional diversity and to move to adopt the best practices. But institutions that are transplanted from abroad with or without the consent of the government are likely to be rejected if there is not, at the same time, a process of adaptation and political mechanisms that sustain this process.

The political framework, is therefore, extremely, since it provides the arena for different interests to emerge in the open, challenge the existing order and eventually bring about the necessary modifications. 
International integration, through institutions such as WTO, OECD, the EU and other regional organisations, may help or force the process of institutional integration. But they cannot be the only vehicle of change if robust political and social consensus is missing.

It is important that each country develop a socially shared vision of where it wants to go and a judgement of the appropriate balance between controlling dictatorship and disorder in order to find the means to achieve its goal. This is a pre-requisite for making institutional changes and policies coherent with stabilisation and growth. Policies may not be equipped to compensate for dramatic institutional changes that take long to deliver. In the Russian sequencing, for instance, of mass privatisation and insiders' takeover, asset stripping, lack of enforcement of contracts and output fall, fiscal policy was unable to fight the fall of tax revenues and give support to the exchange rate policy while facing increasing social needs. But too slow a change cannot provide support to macroeconomic policies either. The sequencing consisting in keeping alive state enterprises through subsidies, soft budget constraints and disincentives to change, cumulative payment and tax arrears, low tax revenues, increasing fiscal deficits, high interest rates, subdue business climate hampering business creation, has been common in less successful transition countries.

While institutional economics does not provide all the answers, it points to the areas where institutions need to be particularly strong to provide for further developments: those are protection of individual property rights, which permeate the whole market incentive mechanisms, and a political process where different interests are represented and institutional reforms come into being through public debate and persuasion. 
${ }^{[1]}$ Douglass C. North, Institutions, Institutional Change and Economic Performance, Cambridge:CUP, 1990, p.3

${ }^{[2]}$ IMF, World Economic Outlook, April 2003, p.97

${ }^{[3]}$ North, cit., p.118

${ }^{[4]}$ Malcolm Rutherford, Institutions in Economics. The Old and the New Institutionalism, Cambridge: CUP, 1996

${ }^{[5]}$ North, cit., p.118

${ }^{[6]}$ This approach is increasingly challenged: see for an insightful criticism Mushtaq H. Khan, "State Failure in

Developing Countries and Strategies of Institutional Reforms, Ppaper presented at ABCDE Conference, Oslo 2426 June 2002.

[7] Beatrice Weder, " Institutional Reform in Transition Economies: How Far Have They Come?" IMF Working Paper/01/114

[8] Transparency International 2003, for instance, ranks Greece, an OECD country, closer to Brazil and far below Israel that precedes France. Singapore is among the first five countries, while the US rank only $18^{\text {th }}$ on this scale.

[9] Jeffrey Sachs, "Institutions Matter, but Not for Everything" Finance and Development, June 2003, pp.38-41

${ }^{[10]}$ Dani Rodrik and Arvind Subramanian "The Primacy of Institutions (and what this does and does not mean)", Finance and Development, June 2003, pp.31-34

[11] John Williamson, From Reform Agenda", Finance and Development, September 2003, p.13

${ }^{[12]}$ Pierre Berthelier, Alain Desdoigts, Jacques Ould Aoudia, » Profils institutionnels. Présentation et analyse d'une base de données originale sur les caractéristiques institutionnelles de pays en développement, en transition et développés «, mimeo Juillet 2003, Paris : Ministère de l’Economie, des Finances et de l’Industrie

${ }^{[13]}$ IMF,WEO, cit., p.97 and 119-120

${ }^{[14]}$ Daniel Kaufmann, Aart Kray and Pablo Zoido-Lobaton, " Aggregate Goovernance Indicators" WB Policy Research Working Paper No.2195, Washington DC, World Bank 1999, and "Governance Matters", WB Policy Research Working Paper, No.2196, Washington DC, WB 1999

${ }^{[15]}$ IMF, WEO,cit., p.98, p.120

[16] Simeon Djankov, Edward L. Glaeser, Raphael La Porta, Florencio Lopez-de-Silanes and Andrew Schleifer, "The New Comparative Economics", CEPR Discussion Paper Series, no.3882, published also in the Journal of Comparative Economics, Vol.31, no.4, December 2003, pp.595-619.

${ }^{[17]}$ This could also occur through changes in property rights that in systems with centralised decision-making are easier to carry out than in defused decision-making processes that characterise democracies, see Avner Greif, "The Emergence of Institutions to Protect Property Rights", mimeo, August 31, 2003.

[18] Thorsten Beck, Asli Demirguc-Kunt and Ross Levine, " Law and Finance: Why Does Legal Origin Matter?" mimeo, August 29, 2002, published in the Journal of Comparative Economics, Vol.31, No.4, December 2003, pp.653-675.

${ }^{101}$ Ibidem, p.665-666

[20] ibidem, pp.658-659

${ }^{[21]}$ Against this point of view Andrei Kuznetsov and Olga Kutnetsova, "Institutions, Business and the State in Russia”, Europe-Asia Studies, vol.55, no.6, September 2003, p.919 argue that Russia would have benefited from other institutional arrangements, such as those of a co-ordinated or organised market economy as opposed to the liberal market economy model; co-ordination being provided by increased powers of the state, but "without providing more leverage for bureaucrats". The problem with such an approach is that the separation line between state and bureaucracy is not an easy one and that administrative reforms designed to clarify the respective field of action are, in general, the most difficult to pass in any country.

${ }^{[22]}$ Thomas Caronthers, "Promoting the Rule of Law Abroad. The Problem of Knowledge", Carnegie

Endowment: Rule of Law Series, no.34, January 2003

${ }^{[23]}$ Cfr. William Tompson,” Reforming Russian Bankruptcy Law”, International Company and Commercial Law Review, 14:4, April 2003

[24] Though in some cases one could argue that the gap between demands (EU) and the capacity of institutional absorption may also have adverse effects on performance in the short-run.

${ }^{[25]}$ Work done in the OECD on FDI indicates such a correlation, although there are no quantitative estimates.

${ }^{[26]}$ IMF, Guidelines on conditionality, mimeo, September 2002.

[27] Joseph Stiglitz "Whither Reform? Ten Years of the Transition" World Bank Annual Conference on Development Economies, Washington D.C., April 26-30, 1999 
[28] Simeon Djankov, Edward L. Glaeser, Raphael La Porta, Florencio Lopez-de-Silanes and Andrew Schleifer, “The New Comparative Economics”, cit.,CEPR Discussion Paper Series, no.3882

[29] This is particularly true for financial and exchange rate policies. Monetary and fiscal policies and trade openness seem less relevant in explaining growth and volatility, but this can be due to the particular type of regression analysis used, see IMF, Chapter on Growth and Institutions, WEO, cit., April 2003, pp.108-111.

${ }^{[30]}$ E. Balcerowicz'comments at a Symposium of the Federal Reserve Bank of Kansas City, mimeo, September 24, 2003

[31] A recent IMF paper suggests that the typical emerging market economy is more vulnerable than developed economy as its sustainable public debt to GDP ratio is only 25 per cent compared to 75 per cent in the latter, see "Public Debt in Emerging Markets: Is It Too High?”, see in the IMF website:

www.imf.org/external/pubs/ft/weo/2003/02/pdf/chapter 3.pdf.

${ }^{[32]}$ For a discussion of regression and stagnation in Tropical African countries, see Thrainn Eggertsson,

"Economic Behaviour and Institutions, Cambridge:CUP 1990, pp.330-332

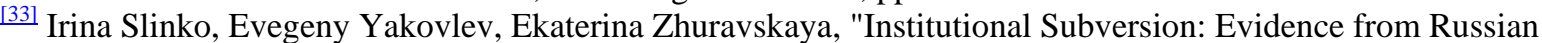
Regions", CEFIR mimeo March 25, 2003

[34] John Coatsworth " Obstacles to Economic Growth in Nineteenth Century Mexico " American Historical Review, 1978, no.83 quoted in North, cit., pp.116-117 